\title{
Predation on the bivalve Macoma balthica by the isopod Saduria entomon: laboratory and field experiments
}

\author{
Gunilla Ejdung ${ }^{1}$, Erik Bonsdorff ${ }^{2}$ \\ ${ }^{1}$ Department of Zoology, University of Stockholm, S-106 91 Stockholm, Sweden \\ ${ }^{2}$ Department of Biology and Husö Biological Station, Âbo Akademi University, SF-20500 Ảbo, Finland
}

\begin{abstract}
Infaunal predators participate in structuring benthic communities by affecting species negatively or positively. The impact of the predatory isopod Saduria entomon (L.) on the bivalve Macoma balthica (L.) was studied in parallel in the laboratory and the field. The hypotheses tested were (1) S. entomon preys on newly settled and small $M$. balthica and (2) $S$. entomon affects the recruiting macrofauna significantly. In the laboratory several experiments with 1 specific size class of $M$. balthica per experiment were performed. Sizes ranged from newly settled postlarvae to $3.2 \mathrm{~mm}$ long specimens. Analysis revealed that $S$. entomon preys actively on $M$. balthica above a certain minimum size $(0.8 \mathrm{~mm})$, and on all the larger sizes tested. In addition, pilot experiments showed that $34 \mathrm{~mm}$ long $S$. entomon were able to open and eat $17 \mathrm{~mm}$ long $M$. balthica, a prey half as large as the predator Recruitment, establishment and early succession were studied in the field. Boxes with and without enclosed $S$. entomon were sampled after $3 \mathrm{mo}$. The assemblages that had developed were similarly diverse and abundant in both treatments. However, $M$. balthica decreased significantly when $S$. entomon was present.
\end{abstract}

\section{INTRODUCTION}

Infaunal communities include many predatory species that participate in the structuring process of these communities (Commito 1982), directly or indirectly (Ambrose 1991, Kneib 1991). Interactions between established adults and newly settled larvae have been suggested as being of importance (Woodin 1976). Larvae in the upper sediment layers were the most vulnerable, affected by predation and disturbance from deposit-feeders (Woodin 1976), e.g. the amphipod Monoporeia affinis (syn. Pontoporeia affinis; cf. Bousfield 1989), a surface deposit-feeder (Lopez \& Elmgren 1989) that preys on the newly settled bivalve Macoma balthica (Elmgren et al. 1986).

The largest invertebrate predator in the northern Baltic Sea, the isopod Saduria entomon, has been shown to influence soft-bottom community structure in shallow Baltic areas (Sandberg \& Bonsdorff 1990). Being a predator on prey with different life habits, we expected $S$. entomon to search for prey both on the sediment surface and in the sediment.

In the field, predatory impacts on fauna have been studied with caging experiments. We present a field study where predator exclusion is compared to predator enclosing. This experiment was designed to test the impact of Saduria entomon on recruiting fauna. A monitoring study indicated that $S$. entomon might regulate the abundance of coinhabitants like Monoporeia affinis and Macoma balthica.

The main aim of this study was to test the following hypotheses while comparing the results of parallel experiments in the laboratory and in the field: (1) Saduria entomon preys on recently settled and small Macoma balthica, and (2) S. entomon significantly affects the recruiting macrofaunal community.

\section{SPECIES DESCRIPTIONS}

\section{Saduria entomon}

The isopod Saduria entomon (L.) (syn. Mesidotea entomon; cf. Bull. Zool. Nomencl. 21: 92-93, 1964) has a circumpolar distribution (McCrimmon \& Bray 1962). It lives in saline, brackish and limnic waters (Apstein 
1909, McCrimmon \& Bray 1962) and inhabits a variety of bottom types, e.g. clay, silt and sand. McCrimmon \& Bray (1962) found the highest density of $S$. entomon in mud bottoms and lowest in sand and gravel bottoms. The vertical distribution in the Baltic ranges from a few decimeters in the Bothnian Sea (Silén 1955) down to $290 \mathrm{~m}$ in the Aland Sea (Haahtela 1990).

Saduria entomon usually stays buried just below the sediment surface, although it can burrow down 5 to $10 \mathrm{~cm}$ in the sediment (pers, obs. in laboratory and field). It can move about and is a good swimmer. Saduria entomon is one of 5 to 6 dominant macrofauna invertebrate predators that occur in the northern Baltic. It is a benthic infaunal 'top' predator that eats a variety of food items, and we have observed scavenging as well as predatory behavior. $S$. entomon has 2 types of chemoreceptors which are important for location of food and feeding: (1) distance chemoreceptors on the antennulae, and (2) contact chemoreceptors on the mouthparts (Pynnönen 1985). Green (1957) observed $S$. entomon to capture living prey such as the isopod Asellus aquaticus (Linn.) and chironomid larvae. Whether $S$. entomon is a visual predator is unknown. Its eyes are quite insensitive to light condition changes with highest spectral sensitivity in the green light (550 nm) (Lindström et al. 1991), which is dominant at the depths where $S$. entomon is common. The main food in the Baltic is probably the amphipod Pontoporeia affinis (Monoporeia affinis) (Hessle 1924) but other invertebrates as well as dead fish are also eaten.

\section{Macoma balthica}

The tellinid bivalve Macoma balthica (L.) is widespread in European and North American temperate and cold waters (Beukema \& Meehan 1985), and is found from very low salinities to fully marine conditions. In the Baltic it occurs from the southernmost parts to about $64^{\circ} \mathrm{N}$ on a variety of sediment types, shallow sandy bottoms as well as deep muddy bottoms.

It spawns mainly in late spring. In the Aland Sea and the Archipelago Sea, spatfall occurs in July (Bonsdorff \& Wenne 1989). After settling and metamorphosis, the newly settled Macoma balthica $(250$ to $300 \mu \mathrm{m})$ lives in the top few $\mathrm{mm}$ of the sediment. It is fully developed at a size of about $2 \mathrm{~mm}$ and feeding is no longer mediated via the foot but through the siphon (Caddy 1969).

\section{MATERIAL AND METHODS}

Study area. The experiments were conducted at Husö Biological Station, Åland Islands, northern Baltic Sea, Finland $\left(60^{\circ} 17^{\prime} \mathrm{N}, 19^{\circ} 49^{\prime} \mathrm{E}\right)$. The field colonization experiment was set up at a semi-sheltered locality outside Gloet Bay in the $\AA$ land archipelago (Bonsdorff 1983). The soft-bottom community studied included 10 to 15 species of macrofauna. Numerically the dominating species are ostracods and mudsnails (Hydrobia spp.) (see Table 2), whereas the bivalves Cardium glaucum and Macoma balthica had the highest biomass values. At least 14 species of meiofauna were present (Bonsdorff 1989, Aarnio et al. 1991), some of which like $M$. balthica were temporary. $M$. balthica dominated numerically in the area and up to ca $20000 \mathrm{M}$. balthica $\mathrm{m}^{-2}$ have been recorded (Bonsdorff \& Blomquist 1989).

General experimental conditions. Laboratory experiments: To test whether Saduria entomon preys on small, recently settled Macoma balthica, 5 laboratory experiments were conducted using different sizes of $M$. balthica, from newly settled postlarvae to small specimens of about $3 \mathrm{~mm}$. For details, temperature and salinity, see text below and Table 1 .

Field experiment: The effect of Saduria entomon on recruiting fauna and especially Macoma balthica was tested in sediment boxes in the field. Hydrographical conditions at the bottom during this experiment were 8 to $19^{\circ} \mathrm{C}, 6.4 \% \mathrm{~S}, \mathrm{pH} 8.1$ to 8.2 , oxygen content 8.9 to $11.4 \mathrm{mg} \mathrm{O}_{2} \mathrm{l}^{-1}$ (94 to $97 \%$ saturation).

Sediment conditions: Sediment collected near the laboratory was sieved through a $1 \mathrm{~mm}$ mesh sieve using a minimum of water, deep-frozen and resieved through a $0.5 \mathrm{~mm}$ mesh sieve. This procedure was repeated for each laboratory experiment in order to get a standardized 'azoic' sediment with natural qualities in terms of food availability and texture. Sand ( $80 \%$ ) was added to the sediment in Expt 1. The organic content of this sediment was several times lower compared to sediment from the other laboratory experiments (see Table 1).

The colonization boxes for the field experiment were filled with defaunated sediment. Drying of sediment for $2 \mathrm{~h}$ at $500^{\circ} \mathrm{C}$ (Ankar \& Elmgren 1976) gave a loss of ignition of $1.0 \%$ for the control, $1.4 \%$ for the experimental, and $1.5 \%$ for the ambient area.

Collection and treatment of animals: Macoma balthica were collected with an Ockelmann sledge $10.5 \mathrm{~mm}$ net) at the same locations as the sediment used in the experiments. Baited traps and an Ekman grab captured Saduria entomon. S. entomon were transferred to storage aquaria connected to the flow water system described below. The ' $M$. balthica' sediment was sieved through an appropriate sieve and the animals retained on the metal net were transferred to a petri dish, carefully picked out with a Pasteur pipette and stored in a refrigerator. When needed the animals were concentrated by pouring off the top layer of the sediment from several vials into a few narrower vials, where small $M$. balthica move readily to the surface, and thereafter repeating the procedure (Elmgren et al. 1986). 
Experimental details. Laboratory experiments: The plastic aquaria had a bottom area of $144 \mathrm{~cm}^{2}$ in Expt 1. and in the other experiments $81 \mathrm{~cm}^{2}$. The incoming water passed through a hole in the top covered with 0.5 $\mathrm{mm}$ mesh net (no net in Expt 1). The outflow hole was located $1.5 \mathrm{~cm}$ below the top on one side and covered with $0.5 \mathrm{~mm}$ net.

Within each experiment, an equal amount of pretreated, thoroughly mixed sediment was added to a depth of 2 to $3 \mathrm{~cm}$. Just before the experiments started Macoma balthica were picked in batches of 25. After sediment compaction the 'prey' organisms were added by pouring an appropriate number of randomly chosen batches into the aquaria to give the desired number of animals (Table 1). M. balthica were added first and allowed to acclimatize before the addition of the predator. According to Caddy (1969) small specimens of $M$. balthica bury within 5 to $10 \mathrm{~s}$ to a depth of 1 to $3 \mathrm{~mm}$ and move around horizontally. After a few hours, 1 approximately $30 \mathrm{~mm}$ long Saduria entomon was added to each aquarium, except the control aquaria (Table 1). Only specimens with intact antennae and antennules were used. Some of the batches of $M$. balthica were not used in the experiments but preserved immediately for control of the initially added number of $M$. balthica and their size distribution.

Extra replicates were started for all treatments, some of which were terminated early and immediately analyzed to help decide when to terminate the other replicates. The replicates were distributed randomly in the aquarium system (cf. Hurlbert 1984). The cooled and filtered water, taken from about 2 to $3 \mathrm{~m}$ depth (Table 1), entered the aquaria via injection needles. The used water filled the containers which held the aquaria, slowing heating of the aquaria by the surrounding air. In addition the containers were covered with insulating material. Water flow rate was ca $0.5 \mathrm{l}$ $\mathrm{h}^{-1}$ per aquarium in all experiments. Temperature and salinity were monitored during the experiments (Table 1).

At termination the aquarium sediment was sieved through a $100 \mu \mathrm{m}$ sieve. The sieve residue was preserved in $4 \%$ buffered formalin stained with Rose Bengal and later sorted and counted under a stereomicroscope. Length measurements of Macoma balthica were made with a MOP-videoplan image-analyzer. Saduria entomon were measured from the anterior cephalon to the tip of the telson.

Field experiment: To test the effect of the infaunal 'top' predator Saduria entomon on the structure and abundance in a zoobenthic community during the phases of recruitment, establishment and early succession, an experiment consisting of 2 treatments was made. These were total exclusion of any macrofaunal

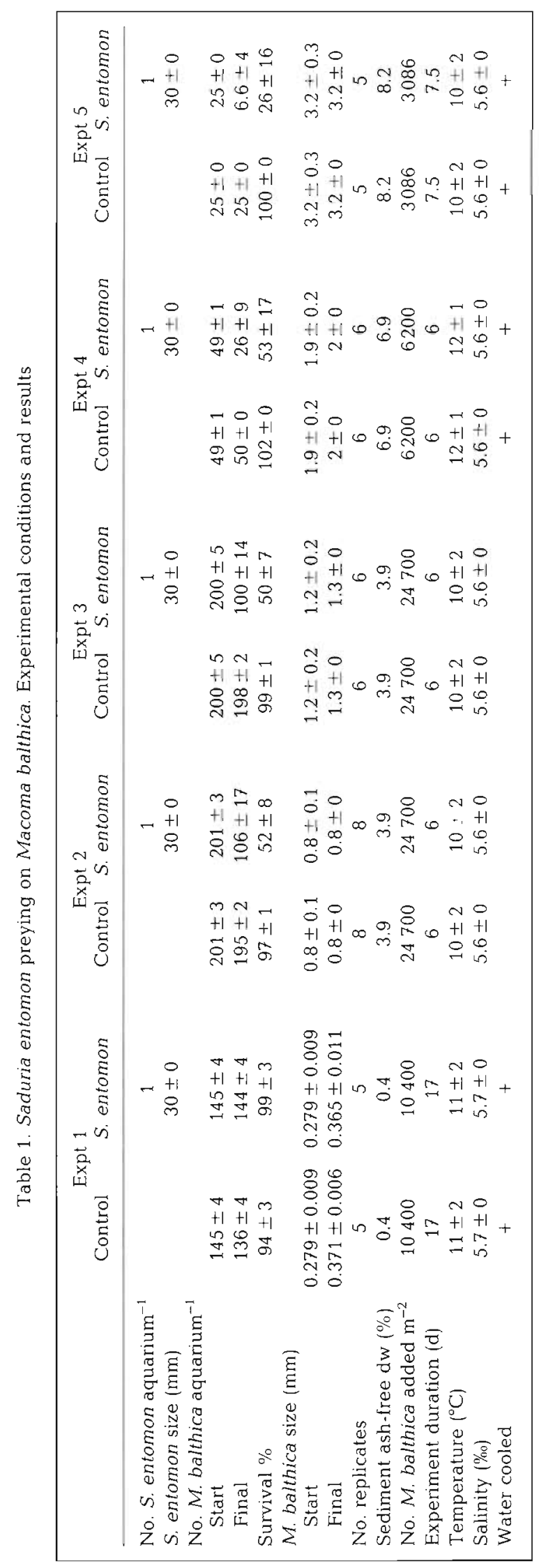


predators, and enclosure of a high density of $S$. entomon. The expected community composition and abundance relationships should be similar in both treatments at the end of the experiment, if $S$. entomon has no effect on the infaunal community

Colonization boxes $(30 \times 40 \times 11 \mathrm{~cm})$, filled with 6 to $8 \mathrm{~cm}$ defaunated sediment and covered with a $0.5 \mathrm{~mm}$ mesh net, were placed at the bottom at $2 \mathrm{~m}$ depth on July 4, 1986, i.e. prior to expected settling of Macoma balthica beginning in the middle of July. The boxes were arranged so as to expose them to the same ambient environmental factors to the greatest extent possible (Connell 1983). Two boxes contained 5 adult Saduria entomon each (length: $48.1 \pm 3.1 \mathrm{~mm}$; weight: $1.77 \pm 0.35 \mathrm{~g} \mathrm{wwt}$ ) equaling 42 ind. $\mathrm{m}^{-2}$, and 2 were left without $S$. entomon to serve as controls. Thus the direct impact of $S$. entomon on the recruiting macrofauna could be tested. The colonization boxes were recovered after 3 mo on October 7,1986 . Ten replicate core samples (diameter: $2.6 \mathrm{~cm} ; 4 \mathrm{~cm}$ deep) were taken from each box. The water and top layer of sediment from the box were sieved through a $250 \mu \mathrm{m}$ net, and the underlying sediment through $0.5 \mathrm{~mm}$ mesh screen. As all comparisons in this experiment are between treatments and not with the ambient environment, each core sample is treated separately as 1 sample unit. Samples from the recruitment area were taken to ensure that the community that was established in the experiment consisted of the natural functional groups. Three replicate box cores with an Ekman-Birge type grab were taken on October 6,1986 . The samples were sieved on a $0.5 \mathrm{~mm}$ mesh screen and preserved like the samples above. All faunal data from the field experiments are given as mean numbers per $\mathrm{m}^{2}( \pm 1 \mathrm{SE})$ to facilitate direct comparison with other field data.

Statistics. The rank-sum test (2-sided) was used for all the statistical testing in the aquaria experiments (Dixon \& Massey 1969). The results from the test for possible differences within and between treatments in the field experiment was analysed by 2 -factor nested analyses of variance. Homogeneity of variances was tested using Cochran's test, and heterogeneity was reduced by square root transformation. A Student's $t$-test tested differences in diversity and evenness.

\section{RESULTS}

\section{Test of interaction between Saduria entomon and Macoma balthica}

Survival. All Saduria entomon survived the experiments. In Expt 1 the number of Macoma balthica surviving in the $S$. entomon treatments was even higher than in the control (Table 1, Fig. 1), but the difference

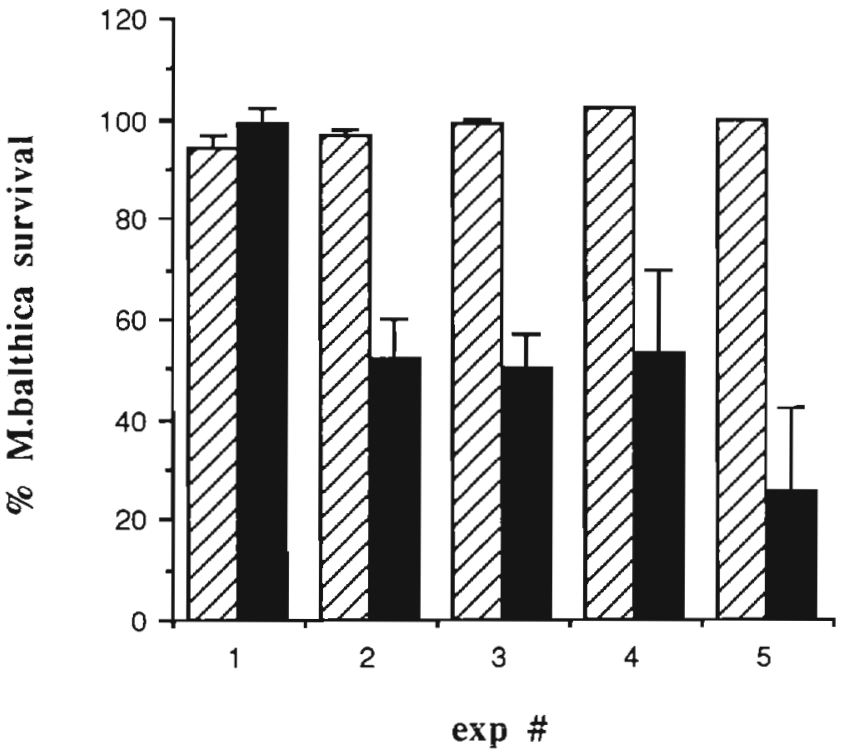

Fig. 1. Saduria entomon preying on Macoma balthica. Percent survival + SE of $M$. balthica in the different aquaria experiments. Hatched columns: control; black columns: predator treatment. Bivalve sizes at the experimental start in Expts 1, 2,

3,4 and 5 were $0.3,0.8,1.2,1.9$ and $3.2 \mathrm{~mm}$ respectively

was not statistically significant (rank-sum test, 2 -sided, $\mathrm{p}>0.11$ ). In the other experiments survival of $M$. balthica in the controls was near $100 \%$ (Table 1), whereas only 50 to $55 \%$ survival was found in the $S$. entomon treatments with 0.8 to $2.0 \mathrm{~mm}$ long $M$. balthica (Expts 2 to 4), and ca $26 \%$ in the $3.2 \mathrm{~mm}$ treatment (Expt 5). Some of the controls showed $>100 \%$ survival since the initial number of $M$. balthica was slightly higher than intended. The difference between control and predator treatment for Expts 2 to 5 was significant $(p<0.004)$. Many empty shells, damaged shells, and bits and pieces of shells were found in the sieve residue. Several of these shells had one half intact whereas the other half was broken off just below the umbo.

Length. In the first experiment a significant increase in the length of Macoma balthica was found during the 17 days of the experiment (Table 1), both in the control and in the Saduria treatment $(\mathrm{p}<0.005)$, but there was no significant length difference between the 2 treatments. Expts 2 to 4 and 5 Iasted only for 6 and $7.5 \mathrm{~d}$ respectively and the animals used were older and slower growing, and no significant length increases were found.

\section{Field experiment}

The natural fauna of the area, 10 to 15 species/taxa, was dominated numerically by ostracods, amphipods (Corophium volutator and Leptocheirus pilosus), mudsnails (Hydrobia spp, and Potamopyrgus jenkinsi), 
Table 2. Abundance of natural fauna (no. $\mathrm{m}^{-2} \pm \mathrm{SE}$ ) in area of the field experiment. The area was sampled $1 \mathrm{~d}$ before end of the box experiment

\begin{tabular}{|lc|}
\hline Faunal component & Abundance \\
\hline Total number of spp & 15 \\
Total abundance & $12145 \pm 621$ \\
Ostracoda & $4145 \pm 491$ \\
Corophium volutator & $2007 \pm 321$ \\
Leptocheirus pilosus & $1811 \pm 787$ \\
Hydrobiidae & $2722 \pm 279$ \\
Macoma balthica & $381 \pm 70$ \\
Chironomidae & $784 \pm 44$ \\
\hline
\end{tabular}

chironomid larvae, and Macoma balthica (Table 2). Of the $M$. balthica, $58 \%$ were $<3 \mathrm{~mm}(27 \%<1 \mathrm{~mm})$, and thus represented stages that could be expected to immigrate to or be transported (Beukema 1973) into the experimental sediments.

During the experimental period all enclosed individuals of Saduria entomon survived in the colonization boxes, and displayed a significant growth of $1.2 \pm$ $0.5 \mathrm{~mm}$ in length, and $0.25 \pm 0.15 \mathrm{~g}$ wwt in weight, indicating that they were able to catch food during the experiment.

After 13 wk of colonization both treatments (control boxes and boxes with enclosed Saduria entomon) had a faunal community as rich in species as the ambient reference (Table 2) (16 species without, and 17 with $S$. entomon; Table 3). No statistically significant difference in species composition or total faunal abundance was registered between treatments (Table 3 ). The abundance of the bivalve Macoma balthica, which occurred in high numbers in the colonization process, was significantly lower $(p<0.05)$ in the presence of $S$. entomon than with total predator exclusion (Table 3), and no difference was found within treatments. In addition, no statistically significant difference in size structure was registered between treatments for $M$. bal- thica. All individuals in both treatments were $<3 \mathrm{~mm}$, with about $60 \%<1.0 \mathrm{~mm}$, indicating that the peak settling period had occurred during the experiment. The abundances of larval chironomids, ostracods, amphipods, oligochaetes, hydrobids and the polychaete Nereis diversicolor were not significantly decreased in the presence of $S$. entomon (Table 3 ).

Although amphipods play an important role in the ambient community, and have been considered as opportunists in previous colonization experiments in the same area (Bonsdorff \& Österman 1985, Bonsdorff 1989), their abundances were very moderate in this study (dominated by the tube building species Leptocheirus pilosus, with $377 \pm 173$ ind. $\mathrm{m}^{-2}$ in the control treatment and $94 \pm 94$ ind $\mathrm{m}^{-2}$ in the Saduria entomon treatment). This is probably due to the relatively late starting date of the experiment, possibly after the peak in recruitment for the amphipods.

The overall community diversity (Shannon-Wiener's $H^{\prime}$ ) and evenness (Pielou's $J$ ) (Gray 1981) did not differ significantly between the treatments ( $\mathrm{p}>0.05$ ) (control: $H^{\prime}=2.532$; with Saduria entomon: $H^{\prime}=2.759$ ), and thus the relative dominance pattern of the community was not significantly altered in spite of the significant effects on species level reported above.

When larger Macoma balthica were present, the predator moved around randomly buried in the sediment as if searching the bottom, or on the sediment surface shovelling the top sediment layer aside. When encountering a bivalve, Saduria entomon pushed it out of the sediment using the head, then grasped and examined the prey. While held with the gnathopods, the bivalve was turned around till the umbo was oriented downwards. Some of the gnathopods moved along the edge of the 2 shells trying to get in between to press them apart. In pilot experiments $34 \mathrm{~mm}$ long $S$. entomon were found to open and eat $17 \mathrm{~mm}$ long $M$. balthica. However, larger animals can withstand the pressure, and occasionally are only injured on the edges of the shell-halves. Whether these wounds affect

Table 3. Abundance values, (no. $\mathrm{m}^{-2} \pm \mathrm{SE}$ with significance levels for any differences between treatments) for the dominating species/taxa from the boxes in the colonization experiment with and without Saduria entomon present. ns: Not significant

\begin{tabular}{|lccc|}
\hline Faunal component & S. entomon & Control & Level of significance \\
\hline Total number of spp. & 17 & 16 & $\mathrm{~ns}$ \\
Total abundance & $17799 \pm 2712$ & $28535 \pm 2828$ & $\mathrm{~ns}$ \\
Nereis diversicolor & $942 \pm 320$ & $1036 \pm 320$ & $\mathrm{~ns}$ \\
Oligochaeta & $1036 \pm 358$ & $283 \pm 151$ & $\mathrm{~ns}^{\mathrm{a}}$ \\
Ostracoda & $4802 \pm 1017$ & $6310 \pm 1544$ & $\mathrm{~ns}^{\mathrm{a}}$ \\
Hydrobiidae & $6310 \pm 1469$ & $10924 \pm 1785$ & $\mathrm{~ns}$ \\
Macoma balthica & $1695 \pm 433$ & $3390 \pm 697$ & $\mathrm{~ns}^{\mathbf{a}}$ \\
Chironomidae & $1036 \pm 320$ & $1789 \pm 603$ & \\
a Square root transformation of data before analysis & & \\
\hline
\end{tabular}


the survival of $M$. balthica is unknown, although predator-caused injuries can be of importance for prey populations (Ambrose 1991).

The type of foraging described above, i.e. the search for food in the sediment, is a slow active hunt opposed to the sit and wait behavior (Green 1957) and the fast active hunt (Pynnönen 1985).

\section{DISCUSSION}

\section{Test of interaction between Saduria entomon and Macoma balthica}

The negative interaction found between Saduria entomon and Macoma balthica in the interaction test is probably due to predation. The control results of $>90 \%$ survival of juvenile $M$. balthica are consistent with the results of Elmgren et al. (1986) and Sandberg \& Bonsdorff (1990). The high survival of newly settled $M$. balthica with a predator present, as found in Expt 1 , could be due to: (1) $M$. balthica being too small to be a food item of interest for $S$. entomon of the size used, (2) $M$. balthica being too small to be detected, and hereby being protected by a size refuge in the sandy sediment, since the sand particles are similar in size to the newly settled bivalve (cf. Reise 1985, Fuller \& Rand 1990).

Predation intensity on larger Macoma balthica was high, ca $50 \%$ or more once the bivalves had reached a length of at least $0.8 \mathrm{~mm}$ (Table 1). Comparing 4 of the experiments $(0.8$ to $3.2 \mathrm{~mm})$ in terms of prey eaten and energy consumed (assuming that all bivalves not recovered were eaten and that an equal number was consumed each day) gives a pattern of $M$. balthica being more susceptible to Saduria entomon predation when they occur at high densities. This is consistent with Sandberg \& Bonsdorff (1990) who recorded higher survival rates with lower prey densities. The energy intake per day during the experiments was highest where prey specimens were largest, but also fewest.

\section{Field experiment}

Previous colonization studies both in the present study area and elsewhere have described the general patterns of succession, and also have stated some methodological restrictions (Arntz \& Rumohr 1982, Bonsdorff \& Osterman 1985, Bonsdorff 1989). Thus the method chosen was thought to be suitable especially with regard to the annual spatfall of Macoma balthica. Also, the replicability of the succession pattern has proved to be good, and similar colonization cages have been used to study the possible effects of both invertebrates and fish in the same region (Aarnio et al. 1991).
The establishment and early succession of the zoobenthic community seems to follow a similar pattern regardless of the presence of the predator, and is primarily governed by 4 factors: (1) the composition of the ambient community, (2) the season of the year, (3) the immigration distance and (4) the biology of the emigrating species (Gore 1982, Fitzhardinge 1983, Bonsdorff 1989). Thus the main colonizers in this experiment probably immigrated through passive transport (with the exception of Macoma balthica, which had its peak in settling at the time of the experiment), and that mechanism seems to be enough to counteract the predatory effect by Saduria entomon at community level, as only the $M$. balthica population was significantly affected. Some other predator-prey field experiments have noted a marked change in diversity in the presence of the predator, as the dominant prey has been affected (Rönn et al. 1988). In this case we assume that the effects on $M$. balthica are due to direct predation, as the results from the aquaria clearly show active predation on the same prey (Sandberg \& Bonsdorff 1990, this study).

The field experiments demonstrate the need for testing also in the field, as laboratory experiments alone can yield rather oversimplified estimates of the importance of the predator (Sandberg \& Bonsdorff 1990, Aarnio et al. 1991). Predation effects are important for the recruiting community, as the newly established individuals are most vulnerable to predation, and in mature communities the network of biotic interactions will be more complex and it may be hard to distinguish the specific effects by a given organism. Thus also intraspecific competition is important in structuring the Macoma balthica population, as shown by Bonsdorff et al. (1986), and 3-level interactions within the sediment or predation by epibenthic organisms (e.g. fish) may affect the community in an unpredictable way (Ambrose 1984b, Mattila \& Bonsdorff 1988). The present field colonization experiment documented, however, that all but one of the recruiting populations were unaffected, i.e. no significant differences were found between control and experimental. The recruitment of Macoma balthica was regulated by Saduria entomon, and $M$. balthica in shallow water certainly is a prey for this omnivorous scavenger, although other organisms have been proposed as its prime food source.

\section{Comparison of field and laboratory experiments}

The abundance of Macoma balthica in the field experiments was reduced by ca $50 \%$. This reduction was confirmed in the laboratory experiments where the abundance decreased with almost $50 \%$ or more once the bivalves had attained a size that was preyed upon. 
Established residents are suggested to affect community structure by inhibiting infaunal settlement, delaying metamorphosis, and influencing survivorship, growth and emigration activity of colonizers (Connell \& Slatyer 1977. Ambrose 1984a, Woodin 1991). Our experiments demonstrated that the resident predator influenced the infauna through predation and by affecting recruitment of Macoma balthica.

Acknowledgements. We thank M. Blomqvist, J. Mattila, C. Rönn and S. Osterman for assisting in the field and laboratory, Husö Biological Station for providing laboratory facilities, C. André for statistical discussions and R. Elmgren for comments on an earlier draft. This work was funded by the Nordic Council for Marine Biology (G.E.), the Academy of Finland (E.B.), and the Natural Science Research Grant (NFR) to R. Elmgren.

\section{LITERATURE CITED}

Aarnio, K., Sandberg, E., Bonsdorff, E. (1991). Benthic predation on shallow-water macro- and meiofauna in the Baltic Sea: an experimental comparison between Pomatoschistus minutus (Pisces) and Saduria entomon (Crustacea). Annls Zool. fenn. 28: $41-48$

Ambrose, W. G. (1984a). Influence of residents on the development of a marine soft-bottom community. J. mar. Res. 42: 633-654

Ambrose, W. G. Jr (1984b). Role of predatory infauna in structuring marine soft-bottom communities. Mar. Ecol. Prog. Ser. 17: 109-115

Ambrose, W. G. (1991). Are infaunal predators important in structuring marine soft-bottom communities? Am. Zool. 31: 849-860

Ankar, S., Elmgren, R. (1976). The benthic macro- and meiofauna of the Askö-Landsort area (northern Baltic proper). A stratified random sampling survey. Contr. Askö Lab., Univ. Stock. 11: 1-115

Apstein, H. (1909). Die Isopoden (Asselkrebse) der Ostsee. Schr naturw. Ver Schlesw.-Holst. 14: 34-50

Arntz, W. E., Rumohr, H. (1982). An experimental study of macrobenthic colonization and succession, and the importance of seasonal variation in temperate latitudes. J. exp. mar. Biol. Ecol. 64: 17-45

Beukema, J. J. (1973). Migration and secondary spatfall of Macoma balthica (L.) in the western part of the Wadden Sea. Neth. J. Zool. 23: 356-357

Beukema, J. J., Meehan, B. W. (1985). Latitudinal variation in linear growth and other shell characteristics of Macoma balthica. Mar. Biol. 90: 27-33

Bonsdorff, E. (1983). Recovery potential of macrozoobenthos from dredging in shallow brackish waters. Proc. 17th Europ. mar. Biol. Symp. Oceanologica Acta vol. spéc.: $27-32$

Bonsdorff, E. (1989). Infaunal colonization and its dependence on environmental variation - experimental evidence from the northern Baltic Sea. In: Ryland, J. S., Tyler, P. A. (eds.) Proc. 23rd Europ. mar. Biol. Symp. Olsen \& Olsen, Fredensborg, p. 349-356

Bonsdorff, E., Blomqvist, E. M. (1989). Do exceptional winters affect the zoobenthos and fish in shallow, brackish archipelago waters? An example from the northern Baltic Sea. Memo. Soc. Fauna Flora fenn. 65: 47-53
Bonsdorff, E., Mattila, J., Rönn, C., Österman, C.-S. (1986). Multidimensional interactions in shallow soft-bottom ecosystems; testing the competitive exclusion principle. Ophelia (Suppl.) 4: 37-44

Bonsdorff, E., Wenne, R. (1989). A comparison of condition indices of Macoma balthica (L.) from the northern and southern Baltic Sea. Neth. J. Zool. 23: 45-55

Bonsdorff, E., Osterman, C.-S. (1985). The establishment, succession and dynamics of a zoobenthic community - an experimental study. In: Gibbs, P. E. (ed.) Proc. 19th Europ. mar Biol. Symp. Cambridge Univ. Press, Cambridge, $p$. 287-297

Bousfield, E. L. (1989). Revised morphological relationships within the amphipod genera Pontoporeia and Gammaracanthus and the 'glacial relict' significance of their postglacial distributions. Can. J. Fish. Aquat. Sci. 46: $1714-1725$

Caddy, J. F. (1969). Development of mantle organs, feeding and locomotion in postlarval Macoma balthica (L.) (Lamellibranchiata). Can. J. Zool. 47: 609-617

Commito, J. A. (1982). Importance of predation by infaunal polychaetes in controlling the structure of a soft-bottom community in Maine, USA. Mar. Biol. 68: 77-81

Connell, J. H. (1983). On the prevalence and relative importance of interspecific competition: evidence from field experiments. Am. Nat. 122: 661-696

Connell, J. H., Slatyer, R. (1977). Mechanisms of succession in natural communities and their role in community stability and organization. Am. Nat. 111: 1119-1144

Dixon, W. J., Massey, F. J. Jr (1969). Introduction to statistical analysis. McGraw-Hill, New York, p. 1-638

Elmgren, R., Ankar, S., Marteleur, B., Ejdung, G. (1986). Adult interference with postlarvae in soft sediments: the Pontoporeia-Macoma example. Ecology 67: 827-836

Fitzhardinge, R. (1983). Comparisons of the invertebrate faunas colonizing soft sediments in two different habitats. Bull. mar. Sci. 33: 745-752

Fuller, R. L., Rand, P. S. (1990). Influence of substrate type on vulnerability of prey to predacious aquatic insects. J. N. Am. Benthol. Soc. 9: 1-8

Gore, J. A. (1982). Benthic invertebrate colonization: source distance effects on community composition. Hydrobiologia 94: 183-193

Gray, J. S. (1981). The ecology of marine sediments. An introduction to the structure and function of benthic communities. Cambridge Univ. Press, Cambridge, p. 1-185

Green, J. (1957). The feeding mechanism of Mesidotea entomon (Linn.) (Crustacea: Isopoda). Proc. zool. Soc. London 129: $245-254$

Haahtela, I. (1990). What do Baltic studies tell us about the isopod Saduria entomon (L.)? Annls Zool. fenn. 27: $269-278$

Hessle, C. (1924). Bottenboniteringar i inre Östersjö. Meddel. K. Lantbruksstyrelsen. 250: 1-52

Hurlbert, S. H. (1984). Pseudoreplication and the design of ecological field experiments. Ecol. Monogr. 54: 187-211

Kneib, R. T. (1991). Indirect effects in experimental studies of marine soft-sediment communities. Am. Zool. 31: 874-885

Lindström, M., Fortelius, W., Meyer-Rochow, V. B. (1991). Exposure to bright light has little effect on eye sensitivity and ultrastructure of Saduria entomon (Crustacea; Isopoda; Valvifera). Zool. Sci. 8: 653-663

Lopez, G., Elmgren, R. (1989). Feeding depths and organic absorption for the deposit-feeding benthic amphipods Pontoporeia affinis and Pontoporeia femorata. Limnol Oceanogr. 34: 982-991

Mattila, J., Bonsdorff, E. (1988). A quantitative estimation of 
fish predation on shallow soft bottom benthos in SW Finland. Kieler Meeresforsch. (Sonderh.) 6: 111--125

McCrimmon, H., Bray, J. (1962). Observations on the Isopod Mesidotea entomon in the Western Canadian Arctic Ocean. J. Fish. Res. Bd Can. 19:489-496

Pynnönen, K. (1985). The structure of long distance (antennular) chemoreceptors in Saduria entomon (L.), Isopoda, and their role in feeding behaviour. Annls Zool. fenn. 22: 423-432

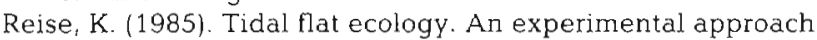
to species interactions. Springer Verlag, Heidelberg, p. $1-191$

Rönn, C., Bonsdorff, E., Nelson, W. G. (1988). Predation as a mechanism of interference within infauna in shallow

This article was submitted to the editor brackish water soft bottoms; experiments with an infauna predator, Nereis diversicolor O.F. Müller. J. exp. mar. Biol. Ecol. 116: 143-157

Sandberg, E., Bonsdorff, E. (1990). On the structuring role of Saduria entomon (L.) on shallow water zoobenthos. Annls Zool. fenn. 27: 279-284

Silén, L. (1955). Några ryggradslösa havsdjur från Ångermanlands kust. Svensk Faunistisk Revy. 17: 110-114

Woodin, S. A. (1976). Adult-larval interactions in dense infaunal assemblages: patterns of abundance. J. mar. Res. 34: $25-41$

Woodin, S. A. (1991). Recruitment of infauna: positive or negative cues? Am. Zool. 31. 797-807

Manuscript first received: May 13, 1992

Revised version accepted: September 22, 1992 